\title{
Os lugares da desordem. Uma geografia legal para a Buenos Aires dos anos 1930
}

Lila Caimari

\section{RESUMO}

O artigo trata do processo de crescimento da cidade de Buenos Aires entre as décadas de 1920 e 1930, detendo-se na relação entre a expansão suburbana e as maneiras de descrever e imaginar as ameaças à ordem e à segurança da cidade. Apoiando-se em fontes jornalísticas e policiais, o trabalho argumenta que nesse período emerge a noçáo de uma ordem portenha contraposta a uma difusa desordem, situada fora dos limites da cidade-capital. Finalmente, analisa este fenômeno em zonas específicas, como o conjunto da zona norte, e a localidade fabril de Avellaneda, situada ao sul da cidade.

Palavras-chave: delito, espaço urbano, polícia, circulação.

\section{ABSTRACT}

This paper analyzes the urban development of Buenos Aires during the 1920s and 1930s. It focuses on the consequences of suburban expansion in the ways the threats to urban order are described. Using journalistic and police sources, it argues that during this period a new notion of a portenho order is born, opposing the regulated city to a diffuse sense of disorder located outside its limits. Finally, the article studies this process as it reflects on representations of specific areas of the suburbs, such as the northern towns, as well as the industrial southern city of Avellaneda.

Keywords: crime, urban space, police, circulation. 
Informa La Razón, em maio de 1929: "Buenos Aires convive com um 'far west' legal em suas próprias portas". Informa La Libertad, em junho de 1932: "A polícia busca em Lanús os autores do tiroteio ocorrido no Once". Informa El Mundo, em janeiro de 1933: "Haviam escondido as armas em um casebre do distrito de Avellaneda". Afirma um informe policial: "Logo os agitadores notaram que já nada podiam fazer dentro da jurisdição da Capital e por isso instalaram-se nos povoados vizinhos, de onde dirigiram seus contínuos ataques".

Este ensaio detém-se em uma mutação da imaginação territorial na cidade de Buenos Aires. Propõe que a sequência urbano-suburbano constitui o suporte de uma estrutura emergente que, a partir do final dos anos 1920, organiza a localização simbólica dos polos do comtinuum da legalidade à ilegalidade, do seguro ao inseguro, da ordem à desordem. Nascida como o próprio subúrbio, de mudanças demográficas e urbanísticas de grande escala, essa expressão da sequência espacial emana de fontes muito diversas, de um imenso agregado de relatos e ocorrências, de discursos de especialistas e de narrativas ficcionais, de textos secretos e de informes públicos. Desse corpus documental, este trabalho ocupa-se principalmente das formulaçôes de maior potencial multiplicador, em particular, do discurso policial sobre a segurança da cidade de Buenos Aires, fonte mais importante sobre as variações desse tema na imprensa "séria" e na popular.

Como agente estatal de uma ordem que se define territorialmente, a polícia produz imagens e descriçôes que configuram simbolicamente os lugares de sua intervenção. Seu discurso supóe um espaço. Segundo as exigências, possibilidades e agendas institucionais, o mapa que o informa vai variando em seus limites e suas ênfases. Juntamente com o acúmulo de informaçóes cotidianas transmitidas ao jornalismo, são filtradas maneiras de pensar a segurança da cidade, suas zonas de risco, a origem desse risco. Nos anos 1930, quando se insinua uma mutação de longo prazo na imaginação espacial, essa operação aparece com nitidez.

A mudança que aqui nos ocupa poderia ser assim resumida: insinuada ao final da década de 1920 e cristalizada em meados da década de 1930, estrutura-se uma sequência entre o legal e o ilegal - ou melhor, entre alta e baixa legalidade, maior ou menor ordem etc. - que opóe a cidade ao seu entorno. Dependendo de que zonas se trate, ou de que formas se olhe, esta configuração territorial reconhece duas inflexôes entrelaçadas. A que os jornais portenhos denunciam é precisa e defensiva. Ela concebe o subúrbio como ameaça à segurança: um "fora" que aloja os focos da delinquência comum e política, latência cujo sentido norteador emana de seu potencial para transformar-se em ato na cidade mais próspera. Marco geral desta concepção, mais difusa e ampliada, a segunda inflexão sugere permissividade, oportunidade de transgressão apenas ocasionalmente realizada. Em muitos sentidos, ambas expressam a oposição entre presença e ausência do Estado, e aludem à conotação vagamente anômica de um subúrbio regido por outro Estado, o da província de Buenos Aires, sem dúvida mais precário e heterogêneo em relação à salvaguarda das regras que regem a cidade.

Não que a cidade de Buenos Aires mereça ser narrada como um espaço da ordem em sentido literal. Alta e baixa legalidade operam como polos simbólicos: disposição de relatividades mais do que distribuição. Em meados dos anos 1930, as autoridades policiais portenhas julgam que suas piores crises de credibilidade tenham passado, graças à expansão normativa que as dotou de novos instrumentos de repressão, e ao equipamento que, nesses anos, havia incrementado o efeito de presença e a pressáo sobre certos setores da sociedade ${ }^{1}$. Nada disso equivale ao controle absoluto do espaço (um princípio sempre relativo que, em todo caso, guarda uma quota de ilusão), mas sim à reversão de uma imagem perdurável de atraso e impotência. Essa reversão também se alimenta do contraste com o (des)controle do extramuros, espaço de possibilidade de práticas que se tornaram legal, ou moralmente, problemáticas na cidade. 


\section{Submundo e subúrbio}

A oposição Buenos Aires/Grande Buenos Aires emerge em uma geografia legal/moral da cidade que já tem marcas enraizadas. A mais persistente é o par bairro miserável/cidade moderna, nascido nas últimas décadas do século XIX, que remete, por sua vez, a outras oposiçôes: ilegalidade/legalidade, sujeira/ limpeza, opacidade/legibilidade, escuridão/luz etc. Buenos Aires - aquela cidade portuária modernizada tão rapidamente - tinha um "submundo" de extraordinária densidade, embora a localização imaginária desta noção sempre tenha sido difusa. Sabemos de seus referenciais mais ou menos específicos: as zonas próximas ao porto (como em tantas cidades portuárias, o porto é o irradiador profuso de "submundo"); os bairros de prostíbulos e de "salóes de bailes", que incluíam ruas do Bajo e da Boca, mas também zonas centrais, como a pracinha do Temple (na esquina de Suipacha com Viamonte); cafés de notória frequência suspeita, como o Cassoulet, com sua sala de bilhar, seus quartos onde se comerciava sexo e sua porta traseira para fugir das razzias; certas zonas fronteiriças entre cidade e pampa, onde os homens tomavam tragos e se desafiavam em duelos a faca... Sabemos, também, que as ruas das zonas próximas ao limite sul concentravam, antes e depois de 1900, o grosso da vigilância policial ${ }^{3}$.

A noção de "submundo" é resistente; nunca desaparece completamente. Ainda hoje há submundo, em alguns rincôes de Buenos Aires, e nostalgia de submundo em sua cultura musical e literária. E, sobretudo, uma elaborada exploração comercial dessa nostalgia em seus circuitos turísticos, procedimento que o tango (música do "submundo" mundializada) levou ao exterior ${ }^{4}$. O indício evocativo do arrabalde sombrio náo desaparece nunca, mas a evoluçáo das condiçóes iniciais de sua gênese (a explosão portuária, a imigração em massa, o desequilíbrio entre os sexos, a condição babélica e provisória das identidades) debilita seu poder ameaçador. O desenvolvimento dos bairros e a modernização do equipamento urbano, que se aceleram nos anos 1920, apagam um pouco, a cada dia, o referencial objetivo dessa confusa "contracidade" das zonas "baixas", lugar de malfeitores, prostitutas e "lunfardos" . A expansão da iluminação elétrica, por exemplo, empurra gradualmente o limite entre os espaços iluminados e os bolsóes escuros para zonas cada vez mais distantes do centro. Entre 1910 e 1930, Buenos Aires passou, de seis mil, para 38 mil postes de iluminação com lâmpadas elétricas ${ }^{6}$. Os significados do avanço da fronteira da luz relacionavam-se (e continuam relacionando-se) ao grande tema do triunfo sobre a escuridão: trata-se de um capítulo-chave da saga ancestral da luta entre a ordem e o caos, ou entre o medo e a segurança. Nas zonas fronteiriças da cidade, aquele simples dispositivo introduzia a luz branca da legalidade na rua. Seu brilho, que deslocava os frágeis lampiōes a querosene, permitia o reconhecimento dos traços únicos e identificáveis de cada indivíduo. $O$ poste na esquina desagregava aglomeraçóes incertas e anunciava outros instrumentos de saneamento e controle do território. Nos bairros operários, a iluminaçáo pública indicava a crescente capacidade estatal para a localização da desordem. Ninguém entende melhor este sentido do que aquele que é objeto desse controle. Durante a Semana Trágica de 1919, a rede de iluminaçáo elétrica é atacada assim que começam os distúrbios. Os enfrentamentos da noite de verão de 9 de janeiro transcorrem na penumbra, e não falta quem arrisque a vida e se lance ao chão, rastejando pelo calçamento para eliminar a última lâmpada que cair de uma fiação, em uma saída de La Boca ${ }^{7}$. Em contextos menos conflituosos, o poste de luz é bem vindo, porque traz garantias consideradas importantes na era do "progresso"; a promessa de segurança pessoal atribuída à luz elétrica é um de seus atributos mais poderosos e duradouros ${ }^{8}$.

Assentados na febre dos loteamentos, na expansão do transporte público e dos equipamentos e na urbanização das "fronteiras", os anos 1920 assistem ao nascimento de um novo imaginário para Buenos Aires, organizado pela oposição centro/bairros. Seus significados subjacentes são morais e estão menos relacionados à questão da ordem, da legalidade, ou da violência. $\mathrm{O}$ tango, as ficçôes folhetinescas e o cinema retrataram muitas vezes esta oposição: o centro é brilhantemente extravagante, tentador e 
eventualmente perigoso para as mulheres inexperientes; o bairro, cenário da ascensão social, é familiar, acolhedor, discretamente trabalhador, um tanto pacato, crítico dos excessos da modernização, mais seguro em suas premissas pequeno-burguesas. Se há um discurso de segurança associado a esse bairro, ele provém da sociedade gregária que o vai construindo, a qual, através de petiçóes e abaixo-assinados, demanda maior vigilância nos novos espaços de assentamento.

O submundo portenho não desaparece, como não desaparecem o porto, o Retiro, nem os prostíbulos incrustados no centro da cidade, nem a trama densa da vida noturna. O jogo clandestino de menor escala não desaparece, nem o tráfico de drogas ${ }^{9}$ se reduz. Mas seu sentido vai ganhando um tom nostálgico, ao mesmo tempo em que se enfraquece um de seus significados originais: o de reverso simétrico da cidade legal, de locus das práticas e das redes delituosas mais ameaçadoras e intrigantes. Estas se transferiram para locais extramuros.

É possível observar essa transformação através dos censos municipais e provinciais de 1936 e 1938 que indicam uma reversão nos padróes de crescimento. O grosso da expansão demográfica da década anterior, que acusa para toda a área metropolitana uns quatro milhóes de habitantes, ocorreu nas localidades exteriores, não nos bairros internos da Capital. $\mathrm{O}$ que até então tinha sido um rosário de núcleos próximos a Buenos Aires - como Quilmes-Bernal, Berazategui-Ezpeleta, San Fernando-Las Conchas - começa a se aglutinar.

Nem todas as localidades da área chegam a fazer parte da zona edificada do subúrbio buenairense, mas as descontinuidades são cada vez mais curtas e são elas, cada vez mais, as que integram o que os demógrafos chamam de "Aglomeração da Grande Buenos Aires" ${ }^{10}$. Com este dado, outra novidade da planificação urbana: a cidade deve estender seu olhar e autoridade administrativa sobre este espaço. Como parte de sua tese de pós-graduação, Carlos María della Paolera (figura-chave na consolidação da disciplina urbanística na Argentina) formula um Plano Regulador da "Aglomeraçáo Buenairense"11. Inspirado em cidades europeias, propôe formas de incorporação das regiôes urbanizadas situadas fora dos limites do perímetro histórico da cidade. As ênfases vão do paisagístico ao funcional, sem demasiada atenção às singularidades dos agrupamentos em questão. Nessas formulações, as conotaçôes sanitárias prevalecem sobre as legais, ou de segurança, uma vez que sobre o pensamento urbanístico pesa a herança higienista que considera os espaços opacos da cidade como focos de miséria, patologia e contágio, necessitados, portanto, de saneamento (material e moral).

O apagamento da noção de submundo origina-se, neste sentido, nas transformaçóes do conceito de arrabalde, subúrbio interno, nessa Buenos Aires cujo enorme perímetro abriga, até a década de 1940, muitas zonas não efetivamente urbanizadas. Quando esses bolsões escuros vão sendo incorporados à malha urbana - quando os serviços sanitários, de eletricidade e viários integram-nos à trama urbana; quando uma sociabilidade característica floresce em cada um -, persiste o sedimento da noção de "submundo", porém deslocado. Seu referencial está agora fora do perímetro da cidade, nessa aglomeração batizada pelos urbanistas dos anos 1930 de "Grande Buenos Aires".

Naturalmente, a "Grande Buenos Aires" não é um "lugar”. Sua coerência emana exclusivamente da oposição à cidade, e, inversamente, une, numa única entidade portenha, bairros muito diferentes em antiguidade e perfil. E nem tudo o que se associa a esse amplíssimo anel suburbano é malsão ou ameaçador. De fato, poder-se-ia dizer o contrário. Quando o arquiportenho jornalista e escritor Roberto Arlt passeia pelos lugarejos dos arredores, vê refúgios edênicos, bálsamos de sossego onde descansar da dança caótica de Buenos Aires. Essas ruas arborizadas tão calmas, "que de cada folha cai um silêncio", são uma sábia negação, "povoados para sonhar, povoados de serenidade”. Ninguém empurra ninguém, "não há círculos de crédulos nem vigilantes nas esquinas" (mas, o quadro não podia ficar assim: na ficção de Arlt, a latência disruptiva desses lugarejos aprazíveis contíguos aparecerá na localização do centro de operaçóes da sociedade secreta de Los siete locos, projeto de conquista de violência delirante e supermoderna, concebido no coração de uma quinta frondosa de Temperley, coberta de madressilvas em flor) ${ }^{12}$. 
O verde, o silêncio, o ar puro. Como em outras metrópoles, as imagens positivas do subúrbio moldam-se em resposta às imagens mais degradadas da cidade, dessa utopia de uniáo do melhor do rural e do urbano $^{13}$. Prolongando a lógica de expansão para os bairros, que segue as linhas ferroviárias em um processo de povoamento tradicional, desenvolvem-se comunidades prósperas e dinâmicas para o sul, o oeste e o norte. Sua existência depende das irradiaçóes econômicas e culturais da cidade e, por sua vez, resulta vital para seu funcionamento. A cada dia, milhares de passageiros industriosos chegam a Buenos Aires de trem e são despejados das estaçôes irradiadoras de Once, Retiro e Constitución no formigueiro do centro histórico ou nas zonas comerciais em pleno desenvolvimento. Essa circulação alimenta a vida econômica e profissional do centro urbano, que alimenta as localidades residenciais dos arredores. É, de acordo com a terminologia de Michel Foucault, circulação positiva - economicamente produtiva, socialmente ordenada, conduzida, mas nunca entorpecida, pelo Estado ${ }^{14}$.

O enorme processo de crescimento da zona metropolitana (que não fará mais do que se acelerar nas décadas seguintes) estabelece as condiçôes para o deslocamento de algumas noçóes de transgressão, da cidade para esse subúrbio de difícil gestão estatal. Entre os anos 1920 e 1930, uma praga de assaltos organizados, ocorridos nas ruas mais respeitáveis da cidade-capital, deu muito que falar em diários e cafés, no rádio e na polícia. Deve-se insistir em um detalhe: nessas operaçóes delituosas, Buenos Aires não passa de um cenário efêmero. Entra-se a partir de fora. E sai-se poucos minutos depois, como se entrou: nesse automóvel que acelera o tempo do delito e que, diferentemente do trem (de deslocamento pautado e previsível), outorga plena autonomia a seus condutores. A figura do "novo delinquente" ingressa em uma tipologia que implica espacialidade ampliada, sustentada na facilidade para entrar e sair da cidade em ritmos imprevisíveis. Buenos Aires é tão somente o marco de uma breve cena (assalto-tiroteio-fuga) planejada longe, em uma territorialidade cada vez mais descentralizada e ampliada ${ }^{15}$.

Para onde escapam táo instantaneamente os delinquentes motorizados? Para essa Grande Buenos Aires, salpicada de gangues, diz o chefe de Investigaçóes da Polícia da Capital, Miguel Viancarlos. Escondidos nas vibrantes localidades que se multiplicam e nos migrantes e imigrantes que iniciam seu próprio sonho da ascensão social, alojam-se os protagonistas do "novo delito". "Os assaltantes mais bem organizados decidiram acampar em localidades vizinhas, assegurando-se assim de uma maior impunidade para o desenvolvimento de suas açôes malévolas e de uma liberdade mais ampla para suas tramadas maquinaçóes criminosas". "A maior proximidade", continua em outro informe, "estimula muitos sujeitos sobejamente conhecidos por seus atos anti-sociais a se internarem com propósitos mal intencionados nesta metrópole, desaparecendo em seguida, o que faz com que nossa ação seja travada pela falta de jurisdição sobre esse tipo de intervenção (...)" ${ }^{16}$. Como a Polícia da Província de Buenos Aires [cuja jurisdição começa nos limites da cidade-capital] não está em condiçóes (nem tem a intenção) de controlar as ilegalidades que cercam a cidade, os ladróes motorizados não necessitam escapar para muito longe para evitar transtornos, continua Viancarlos. De uma constelação de falsos cafés, falsos comércios e casas de jogo dissimuladas, escolhidos por sua proximidade da cidade mais rica, "saíram os delinquentes que operam ultimamente na Capital Buenos Aires". Trata-se, então, da transformação de toda uma geografia da transgressão. E de uma novidade do imaginário urbano destinada a ter longa vida: a associação entre o delito, a desordem e a "Grande Buenos Aires". A circulação automotora introduz na cidade a legalidade imprecisa dos subúrbios (um velho núcleo do pensamento urbanístico). A governabilidade dos "povoados circunvizinhos" passa a ser um problema de Buenos Aires.

O mais distraído leitor de diários portenhos conhece o mapa da desordem que vai se sedimentando na imprensa comercial. As ruas deste ou daquele bairro, que durante décadas teceram a trama espacial da nota policial, mesclam-se com nomes de distritos e localidades cada vez mais distantes. Avellaneda, Lanús, Valentín Alsina, Morón, Lomas de Zamora, Matanza, Vicente López, San Fernando... A nomenclatura estabelece-se mediante histórias de baixa intensidade. Um tiroteio aqui, outro ali. Uma batida policial, um assalto intempestivo, um enfrentamento armado entre facçóes, uma disputa que se 
transforma em homicídio, dois sujeitos que trocam tiros em uma avenida descampada e poeirenta... De vez em quando, as implicaçóes da ilegalidade endêmica e contígua passam ao primeiro plano, com o titular do "grande assalto" no centro, perpetrado por bandos provenientes dos "povoados vizinhos". Ali, nesses cenários incertos, estão seus "esconderijos". O termo - que evoca covis de animais, disfarçados em uma paisagem sem cultura -, cujo significado é exatamente oposto à artificialidade da ordem urbana, é muitas vezes mencionado na crônica policial (dos jornais e da polícia).

A ocorrência da desordem suburbana está demarcada por eixos, cujas conotaçóes são bem diferenciadas. Para o norte: Vicente López, Florida, Olivos, San Isidro e San Fernando. Os nomes, que seguem a linha ferroviária, remetem ao sentido "suave" da promessa suburbana: o da possibilidade de relaxamento dos controles, da proximidade da cidade sem o labirinto da cidade. Nesse corredor de ar livre, do prazer do verde e das praias ribeirinhas há uma promessa de distensão, inclusive para quem não é dono de quintas. São os anos da descoberta do week-end. A revista ilustrada Caras y Caretas assim descreve os quentes domingos de 1929: "Enorme movimento de trens. Todo mundo escapa para os balneários populares do norte. Piqueniques, corridas, sol, calor, cerveja. Quando um pobre se diverte... se diverte!" 17 Milhares de portenhos acorrem para refrescar-se (literal e figuradamente) no litoral de Vicente López, Martínez e Olivos. E naturalmente, os excessos de fala e de comportamento nesses espaços suscitam na imprensa arrogantes conclamaçóes à vigilância dos costumes daquela "turba grosseira" que perde seus controles morais habituais ${ }^{18}$.

Paralelamente, vislumbra-se naquela área um mercado apenas dissimulado de práticas clandestinas, mas socialmente toleradas. Em 1925, o intendente de Buenos Aires, Carlos Noel, proíbe a construção de mais prostíbulos na cidade. Muitos, contudo, persistem, disfarçados nos novos edifícios de apartamentos. Mas, ao compasso das posturas municipais e do importante avanço legislativo e policial contra o tráfico de mulheres, uma parte do negócio se desloca para a periferia. $\mathrm{O}$ eixo norte constitui um lugar conhecido de oferta sexual. E em dimensóes mais escandalosas, o mesmo está acontecendo com o jogo.

Nenhuma forma de entretenimento está mais arraigada e é mais popular do que o jogo. Em Buenos Aires, todos são candidatos a milionários, e não há um pobre coitado que não perambule apregoando seu "palpite", diz nosso ácido testemunho dos costumes, Roberto Arlt ${ }^{19}$. Certamente não faltam oportunidades, legais ou clandestinas, de canalizar esse impulso. Comecemos pelas apostas nas corridas de cavalos. Sua furtiva difusão, que tanta violência gera nas lutas pelo controle do caixa, é função de sua legitimidade social, que prolonga em escala reduzida o magnetismo das grandes vitrines do turfe, verdadeira obsessão de época. Ao hipódromo de Palermo afluem figuras da política, personalidades da alta sociedade, celebridades do entretenimento, um e outro chefe do crime, e muitos milhares de apostadores anônimos. Centro de atividade febril, o hipódromo é assunto para seções fixas de jornais e revistas (incluídas as da polícia), tem analistas especializados e uma galeria de estrelas extremamente populares. O hipódromo é uma encruzilhada da vida política, social e econômica, o polo mais brilhante de toda uma cultura do jogo de azar, grande, pequeno e minúsculo, que se confunde com as próprias formas da sociabilidade.

Buenos Aires, cidade das quinielas ${ }^{20}$ e dos radicais, afirma Arlt. Tributário ilegal de outro jogo legal (a loteria), a quiniela é o jogo de azar dos menos abastados. Por sua capacidade para filtrar-se na infinidade de gastos domésticos, faz sucesso entre as donas de casa modestas - e seus "corretores" não faltam nos açougues, quitandas e armazéns. O comissário Romariz recorda, em suas memórias, que as freguesas separavam uns centavos da quantia destinada à compra de mantimentos para reservá-los às apostas, e que esses mesmos vendedores anotavam os dados em um boleto que entregavam junto com o pão e o leite.

A quiniela não é igualmente popular em todas as partes. Arlt assegura que os bairros de pequenos proprietários recentes são um mau endereço para os "corretores", que encontram seu paraíso nas zonas mais pobres e antigas - Boedo e San Juan, Triunvirato e Concepción Arenal - "isto é, esses centros de população onde cada família ocupa uma peça que não é própria, mas sim alugada (...). 
[Ali, os quinieleros] têm implantada sua banca nos mercados, contando com cúmplices entre os empregados dos açougues, que são os mais afeitos aos jogos por palpite" 21 .

Nesse marco, os "povoados vizinhos" funcionam como uma prolongação protetora e indulgente do mais notável desses costumes do ócio, frequentes na Capital, onde florescem as quinielas de bairros, enquanto as casas de apostas e os prostíbulos vão se tornando mais raros. $\mathrm{O}$ status legal desse conjunto de práticas chamadas “jogo" coloca dilemas permanentes à legislatura provincial de Buenos Aires, que oscila entre o proibicionismo e as permissóes parciais (às corridas de cavalos e à loteria, por exemplo), entre a condenaçáo moral e o pragmatismo. O debate no interior do conservadorismo sobre a conveniência de legalizar os cassinos com a finalidade de coletar fundos para obras sociais termina se resolvendo pela negativa, mantendo-se, assim, essas conhecidas atividades em (simulada) clandestinidade ao longo da década $^{22}$. Com este status, o jogo cumpre uma função fundamental de financiamento da política provincial, é o centro nevrálgico do controle territorial caudilhista da era conservadora.

Toda iniciativa de erradicação dos perniciosos costumes dos jogos de azar está destinada ao fracasso, denuncia La Prensa, enquanto casas de jogo continuarem sendo instaladas nas proximidades de Buenos Aires, "que embora pertençam à jurisdição da província, podem ser consideradas, em relação aos bairros metropolitanos, como verdadeiras prolongaçóes dos mesmos, sem solução de continuidade". As casas de apostas, dissimuladas atrás de fachadas mais ou menos respeitáveis se multiplicam, ignorando as proibiçóes, justamente pela promessa de abundante clientela que a proximidade da rica e populosa Capital lhes proporciona ${ }^{23}$. Como todo mundo sabe, em Tigre funciona um cassino que nem sequer se disfarça como um clube social com outros fins. Suas dimensóes provocam reclamaçóes por parte das autoridades de Mar del Plata, impossibilitadas de habilitar os próprios cassinos pela mesma proibição legal, tão escandalosamente burlada na Grande Buenos Aires. Enquanto isso, as roletas e as partidas de naipes, que se joga nas residências luxuosas, atraem um fluxo importante de participantes. Disso sabe bem o empregado do cassino do balneário atlântico, que, ao final da temporada de verão, coloca suas habilidades a serviço do jogo que (com clientela portenha e buenairense) prolifera nas mansóes das quintas privadas de Martínez, Acassuso, San Isidro... ${ }^{24}$ Denunciam editoriais:

De Bahía Blanca a Lincoln, de San Nicolás a Trenque-Lauquen e Pehuajó, e sobretudo nos arredores da Capital, como Avellaneda, Cidadela, Florida, Olivos, San Isidro, San Fernando e Quilmes, joga-se desde a manhã até de noite, sem que as autoridades policiais percebam, que isso pressupóe sua cumplicidade e tolerância. ${ }^{25}$

A questão é que, além de gerar reflexóes amargas sobre a moral dos tempos, a ubiquidade do jogo em suas expressóes mais escandalosas coloca em cena a conivência da polícia de Buenos Aires. Afirma La Prensa:

Seria quase absurdo alegar ignorância da existência de uma roleta à qual concorre um número tão grande de jogadores, certamente não radicados na localidade e necessitados, em consequência, de todos os meios possíveis de transporte, especialmente do automóvel, para chegar ao local em que aquela está instalada. Será que a caravana de carros, todas as noites, no mesmo horário, sobretudo o da volta, não sugeriu nada à chefatura de política de Tigre? ${ }^{26}$

Muitas denúncias apontam para a corrupção policial e para esse difuso marco de aquiescência que permitiu a conexão progressiva entre os povoados vizinhos e a Capital. Mas, se cassinos e prostíbulos constituem uma ameaça aos portenhos, isso ocorre apenas como parte de oportunidades de entretenimento que são bem vindas, e só em sentido moral. A dimensão violenta da Grande Buenos Aires aparece associada ao eixo sul, prolongamento do submundo histórico das zonas do porto, nas imediaçóes do Retiro e do Riachuelo. O polo de medos e denúncias está bem implantado às portas da cidade, na populosa Avellaneda. 


\title{
Do outro lado da ponte
}

\author{
Do outro lado da ponte, Itudo é jogo e alegria, \\ e embora se mate gente, la polícia nada vê.
}

Publicada pela primeira vez na revista portenha Caras y Caretas, a canção contrasta "os dois lados da ponte" que une as margens do Riachuelo (limite sul entre a cidade e a província de Buenos Aires) e está acompanhada de um desenho que representa a desordem, a tolerância grotesca, o transbordamento dos vícios e a complacência policial de um lado; a silhueta elegante dos edifícios modernos, do outro.

Avellaneda constitui o núcleo de uma verdadeira lenda em torno da ilegalidade do subúrbio, embora suas conotaçôes sejam muito específicas e diferentes das de outras localidades. Em primeiro lugar, o nome náo evoca a genérica anomia da paisagem semi-rural, mas sim a trama densa e violenta, composta por muitos elementos combustíveis. Avellaneda é um centro urbano, um polo fabril, a localidade mais povoada da província, um impetuoso núcleo situado exatamente extramuros. Ou "extra ponte", para ser mais preciso, pois a cidade está separada de Buenos Aires pela movimentadíssima ponte Pueyrredón. Proximidade e volatilidade, espaço do jogo proibido, de prostíbulos, de violência política e sindical, refúgio de gangues amparadas por caudilhos e policiais amigos de caudilhos... Avellaneda exibe, em escala, muitos traços do "pistoleirismo" do entreguerras. "Não se pode esquecer", sublinha La Nación, "que tais acontecimentos são produzidos exatamente nas portas da grande capital, e em um distrito que, por si só, representa a terceira concentração do país em população e em interesses comerciais e industriais estabelecidos"27. Este "paraíso da escória" está "colado" a Buenos Aires.

Pode-se dizer que os estabelecimentos comerciais das ruas centrais de Avellaneda são a fachada apenas velada de negócios clandestinos. Sobre o jogo: "Não é exagerado dizer que a maioria dos locais existentes na Avenida Mitre, desde a ponte Pueyrreón até a praça local, está destinada a agências disfarçadas de loteria, que não são senão casas de jogo clandestinas nas quais as infrações são cometidas sem nenhuma repressão", afirma La Prensa. Sobre a prostituição: vagamente dissimulada, por detrás das fachadas de supostas barbearias, charutarias ou restaurantes, oferece-se sexo ao transeunte mais inocente "em pleno centro de Avellaneda, em locais não muito distantes da primeira delegacia de polícia”, afirma o jornal $\operatorname{local}^{28}$. As casas clandestinas de jogo, quinielas e roletas em clubes sociais são segredos conhecidos por todos. Um luxuoso cassino clandestino, com tapetes, lâmpadas de teto e baixela de prata, funciona há muito tempo nos fundos do Centro de Fomento Avellaneda, administrado por Juan Tink - amigo do coronel Ramón Falcón e aliado de Marcelino Ugarte entre 1914 e 1917 - e herdado depois pelo caudilho local, Alberto Barceló.

Pibe Ruggiero, o valentão Ruggierito, dirige uma conhecida casa de jogo clandestina. Um cartaz que não dá margem a dúvidas - "Façam suas Apostas Hoje" - anuncia as atividades da jornada. Estrategicamente situado junto à saída da cidade, o estabelecimento oferece garantias de proteção contra assaltos no caminho de volta para casa. "Se o roubam na Capital, você está ferrado, mas aqui em Avellaneda, nunca assaltam um cliente meu”, é a estratégia comercial do patrão ${ }^{29}$. Os centros de jogo operam com clientela local e também com milhares de habitués que vêm do outro lado do rio: sua contiguidade à cidade mais rica explica sua expansão continuada. $\mathrm{O}$ detalhe raramente é mencionado nas crônicas jornalísticas, nas quais as casas de jogo da cidade vizinha aparecem como um fenômeno alheio e exótico.

Mais importante que as roletas e os jogos de cartas é o volume de apostas clandestinas vinculadas às corridas de cavalos. "Na Avenida Mitre funciona aos sábados e domingos um hipódromo completo em miniatura, onde se reúnem habitualmente cerca de 1.000 pessoas". A magnitude das infraçóes é descomunal, continua, escandalizado, o cronista de La Prensa, e a única diligência policial consiste em ordenar o trânsito do público para que todos possam chegar aos guichês e fazer suas apostas. Enquanto 
isso, de um terraço da Avenida Vértiz, atual Libertador, são recebidas, por telefone, as apostas para cada corrida do Hipódromo de Palermo (a transmissão radiotelefônica dos resultados é reiteradamente proibida, precisamente para evitar o jogo clandestino). No estabelecimento da Rua Pavón (gerenciado por Pibe Ruggiero), os apostadores ouvem ao vivo, por alto-falante, o relato das corridas.

Os jornais denunciam: a polícia de Avellaneda náo cumpre suas funçóes - falta de efetivos e falta de vontade. "A Polícia da Província, além de permitir os jogos de azar, protege, com zelo, as casas de apostas. O aumento do jogo, percebido em algumas localidades, ganha características extremas em Avellaneda“. A frustrada reforma policial, iniciada pelo governador Manuel Fresco em 1936, mostra até que ponto o vínculo entre caudilhismo, polícia e jogo minou o poder das autoridades da instituição. Os chefes da Polícia de Buenos Aires observam, impotentes, a autonomia de seus funcionários. A órbita imantada do cofre dos caudilhos locais, cuja origem principal é o jogo clandestino e também a prostituiçáo, burla cada tentativa de organizar o disperso poder policial dessa enorme província em torno de um centro, em La Plata ${ }^{30}$.

Mais ostensivamente permissiva que outros subúrbios, a Avellaneda dos anos 1930 é também a mais violenta. Assim recorda Jorge Luís Borges em La muerte y la brújula (1944): "Ao sul da cidade do meu conto flui um riacho cego, de águas barrentas, aviltado por curtumes e imundícies. Do outro lado, há um subúrbio fabril onde, ao amparo de um caudilho barcelonês, vicejam os pistoleiros". Separados de Buenos Aires por uma profusão de lama e lixo, os pistoleiros do subúrbio fabril "vicejam" - o inquietante verbo não pode ser casual.

O "pistoleirismo" suburbano é um subproduto dos mesmos conflitos políticos que estruturam a territorialidade do jogo clandestino. Seu sucesso de público transforma-o em um butim que se dissolve em escândalo. A morte do "conhecido explorador", Oscar Modelo, "El Pibe Oscar", nas mãos de seus inimigos de bandidagem, por exemplo, merece grandes manchetes da imprensa portenha ${ }^{31}$. Acerto de contas entre senhores do jogo, portanto. Mas, também, no mundo da política (que nem sempre se distingue claramente desses espaços rentáveis de lazer). A queda de Juan Ruggiero ("Ruggierito"), em outubro de 1933, é emblemática das lutas territoriais entre bandos, e da ameaça de transbordamento da violência periférica na cidade. Chefe da tropa de choque do caudilho local Alberto Barceló, Ruggiero é uma figura associada ao mesmo tempo às modulaçóes mais baixas da "baixa" política, e a seus desvios populistas. Atua, vimos, como chefe de uma rede de prostíbulos e de casas de jogo da zona. Entre 1929 e 1930, seu enfrentamento com o pistoleiro Julio Valea, "O Galego Julio", projeta-se para muito além dos limites do "submundo" suburbano. A luta "não era travada nem em Avellaneda, nem em Barracas, nem sequer na Boca, mas sim chegou com o estrépito das armas automáticas à Rua Suipacha, nos arredores da estação Constitución e na Avenida de Maio”, recorda El Mundo em seu obituário. Valea é finalmente executado durante uma corrida no hipódromo de Palermo. "Ruggierito" sobrevive a ele e escapa de vários atentados à sua vida. Em outubro de 1933, morre assassinado nas ruas de sua cidade. Suas exéquias geram maciças manifestaçôes de pesar ${ }^{32}$.

Outros pistoleiros respondem às ordens de líderes sindicais ou de tropas de choque de caudilhos conservadores. Outros, ainda, participam de disputas no interior dos sindicatos ou de confrontos entre fraçôes anarquistas - essa lógica se adivinha na longa série de incêndios, tiroteios e bombas em padarias noticiados pela imprensa local ${ }^{33}$. Alguns incidentes entre o mais "bravo" da polícia "brava" e manifestaçôes de uma dissidência enfurecida inundam a primeira página dos jornais. Em junho de 1931, o interventor da polícia do distrito, José Rosasco, é crivado de balas enquanto janta no tradicional restaurante Cecchin, em pleno centro da cidade, a uma quadra da delegacia de investigaçóes e a duas da Avenida Mitre. "Foi uma coisa cinematográfica", disse uma testemunha que jantava numa mesa próxima. Disfarçados como um grupo de clientes elegantes (na cena do crime deixam atrás de si um sapato de verniz e óculos com armação de tartaruga), os atacantes avançam sobre a mesa em questão, descarregam cinco balaços de suas pistolas calibre 45 de última geração sobre o major Rosasco, e fogem em dois automóveis estacionados na porta ${ }^{34}$. 
Por volta de meados dos anos 1930, a reputação de Avellaneda como subúrbio "barra pesada" está estabelecida e é explorada comercialmente. Os valentôes são comparados aos gangsters, seus irmãos mais velhos do grande crime de Chicago que projetam um halo de profissionalismo e poder tecnológico. $\mathrm{O}$ aparecimento de uma metralhadora em um tiroteio entre bandos, por exemplo, inspira os cronistas de Crítica e da popular revista Ahora à mesma analogia entre Ruggierito e o chefe mafioso Al Capone, entre os "pistoleiros criollos" e a máfia de Chicago ${ }^{35}$.

O quanto há de exagero nesta imagem? Há uma glamorização estilística, mas não muito mais do que isso. As estatísticas disponíveis - que unificam as distintas lógicas da violência, mas mantendo a proporção - tendem a confirmar o quadro impressionista da imprensa (embora sem os adornos hollywoodianos). Nas décadas de 1920 e 1930, a população de Avellaneda cresceu extraordinariamente, e mais extraordinariamente ainda cresceu sua taxa de delitos. O salto mais nítido ocorreu no período entre 1925 e $1939^{36}$.

Esses números referem-se muito mais aos perigos que os avellanedenses correm do que àqueles que ameaçam os portenhos. Falam de uma violência que é local, de acidentes, tiroteios, assaltos... Várias vezes por semana (ou várias vezes por dia) a imprensa da cidade narra as peripécias dessa história ${ }^{37}$. A eventual ameaça à Capital mal aparece (ou não aparece em absoluto), e sim alude ao potencial estigmatizante do fenômeno delituoso, tal como é apresentado em seus grandes diários. "Avellaneda, como acredita a imprensa metropolitana, não é um esconderijo de delinquentes", responde o titular de $L a$ Libertad à crônica de La Nación. Há bandos, sim - afirma outro diário local, La Opinión -, mas é pelo aumento do patrulhamento expulsivo da Capital, que obriga suas vizinhas a terem que lidar com criminosos que provêm de Buenos Aires e pertencem a Buenos Aires ${ }^{38}$.

Inseridos em um contexto de sentido mais amplo e inteligível, a violência, a falta de vigilância e a lógica corrupta da Polícia de Buenos Aires são tematizadas cotidianamente. E coexistem, sobretudo, com demandas comunitárias, relacionadas aos pedidos de obras de higiene pública e de desenvolvimento de uma infra-estrutura que acompanhe o crescimento demográfico. $\mathrm{O}$ tema da precariedade legal que os grandes jornais difundem - e o pacto entre poder político, polícia e prática ilegal do jogo - aparece conectado ao que isso representa para a vida cotidiana da populaçáo. E mais: retiradas dos jornais de Buenos Aires e reinseridas no contexto local, essas notícias são ressignificadas e utilizadas seletivamente para criticar as autoridades locais (conservadoras). Elas resistem ao sentido portenho que lhes é atribuído: o "cerco" de Buenos Aires não é assim; e a lenda negra de Avellaneda traduz-se em reclamos de proteção para os milhares de trabalhadores que alimentam a vida de fábricas e frigoríficos e para as suas famílias que nutrem o tecido econômico, social e comercial desse centro urbano de impetuosa vitalidade ${ }^{39}$.

Essa queixa por "mais polícia" é comum a muitas outras localidades bonaerenses, e se aproxima do que ecoa nos bairros da própria Capital. Mais ampla, muito mais urgente, a demanda recorta uma expectativa que define a polícia ideal, em oposição a essa força policial, cuja lógica da violência não se distingue bem da que penetra a própria sociedade, que se confunde com seus vícios, com a dinâmica insurgente de sua política. A débil polícia dos abaixo-assinados de moradores e dos editoriais da imprensa comunitária deve ser uma força civilizatória. Como nos bairros portenhos, clama-se por uma força policial capaz de garantir uma ordem (social, territorial) que permita o desenvolvimento do projeto daqueles que chegaram a essas localidades em plena expansão, de suas comunidades européias, ou das províncias do interior. Que lhes permita, enfim, realizar algumas das amplas promessas de ascensão social ${ }^{40}$.

Tradução: Sérgio Lamarão Revisão técnica e edição: Maria Aparecida Rezende Mota 


\section{Notas}

${ }^{1}$ CAIMARI, Lila. En guerra contra el hampa. Políciay modernización tecnológica en el Buenos Aires de los años trinta. In: BOHOSLAVSKY, E., CAIMARI, L. e SCHETTINI, C. (eds.). La policia en perspectiva historica. Argentina y Brasil (desde el siglo XIX a la actualidad. Disponível em: <http://www.crimenysociedad.com.ar/files>

${ }^{2}$ No original, "peringundines". Nota do Editor.

${ }^{3}$ Para a distribuição dos cafés portenhos do final do século XIX, ver GAYOL, Sandra. Sociabilidad en Buenos Aires. Buenos Aires: Ediciones del Signo, 2000, p. 36 e 42. Para a localização dos prostíbulos, ver GUY, Donna. El sexo peligroso. La prostitución legal en Buenos Aires, 1875-1955. Buenos Aires: Sudamericana, 1994, cap. 3; CARIDE, Horacio. Una aproximación a la historia prostibularia de Buenos Aires en tiempos de la "legalidad". Trabalho apresentado em "Fuera de la ley. Jornadas de discusión sobre delito, polícia e justicia en perspectiva historica (siglos XIX e XX)”, Buenos Aires, Universidad de San Andrés, 17 e 18 de junho de 2010. Sobre a distribuição da vigilância policial em finais do século XIX, ver GALEANO, Diego. La policía en la ciudad de Buenos Aires, 1867-1880. Dissertação de Mestrado em Investigação Histórica, Universidad de San Andrés, 2010, p. $132-137$.

${ }^{4}$ Conta o bandoneonista José Libertella que para divulgar seu show em Paris, em 1981, Le Monde o descrevia como um espetáculo de "trinta e três artistas do submundo de Buenos Aires". FONDEBRIDER, Jorge (comp.). La París de los argentinos. Buenos Aires: Bajo la Luna, 2010, p. 426.

${ }^{5}$ Lunfardo, de acordo com a definição do Dicionário Houaiss da Língua Portuguesa, é a gíria argentina, originada da variação dialectológica dos imigrantes italianos, que se fixa nas classes baixas (frequentemente usada em letras de tangos).

${ }^{6}$ LIERNUR, Jorge F. Arquitectura en la Argentina del siglo XX. La construcción de la modernidad. Buenos Aires: Fondo Nacional de las Artes, 2001, p. 104.

${ }^{7}$ ROMARIZ, José R. La Semana Trágica. Buenos Aires: Editorial Hemisferio, 1952, p. 88.

${ }^{8}$ Dominique Kalifa examina esta associação em "L'attaque nocturne, une frayeur". Ver Crime et culture au XIXe siècle. Paris: Perrin, 2005, p. 249. Sobre a trama de associaçôes culturais que evoca a irupção da iluminação da rua, ver SCHIVELBUSCH, Wolfgang. Disenchanted Night: The Industrialization of Light in the Nineteenth Century. Berkeley, Califórnia: University of California Press, 1995. Sobre a expansão da iluminação em Buenos Aires, ver "El torbellino de la electrificación. Buenos Aires, 1880-1930”, em LIERNUR, Juan F.; SILVESTRI, Graciela. El umbral de la metrópolis. Transformaciones técnicas y cultura en la modernización de Buenos Aires, 1870-1930. Buenos Aires: Sudamericana, 1993.

${ }^{9}$ No original, "alcaloides". O Diccionario de la lengua española de la Real Academia Española, define alcaloide como "cada uno de los compuestos orgánicos nitrogenados de carácter básico producidos casi exclusivamente por vegetales. En su mayoría producen acciones fisiológicas características, en que se basa la acción de ciertas drogas, como la morfina, la cocaína y la nicotina. Muchos se obtienen por síntesis química”. Nota do Editor.

${ }^{10}$ VAPNARSKY, César. La Aglomeración Gran Buenos Aires. Expansión espacial y crescimento demográfico entre 1869 y 1991. Buenos Aires: EUDEBA, 2000, cap. 8.

${ }^{11}$ Sobre o desenvolvimento da noção do conjunto urbano bonaerense, ver CARIDE, Horacio. La idea del conurbano bonaerense, 1925-1947. Documento de Trabajo No 14, San Miguel: Instituto del Conurbano, UNGS, 1999; NOVICK, Alicia; CARIDE, Horacio. La construction de la banlieue à Buenos Aires. In: RIVIERE D’ARC, H. (dir.). Nommer les nouveaux territoires urbains. Paris: UNESCO/ Editions de la Maison des Sciences de l'Homme, 2001, p. 105-130.

12 ARLT, Roberto. Pueblos de los alrededores. El Mundo, 31 de marzo de 1929; Idem. Los siete locos. In: ARLT, Roberto. Novelas. Buenos Aires: Losada, 1997 [1929].

${ }^{13}$ TUAN, Yi-Fu. Topophilia. A Study of Environmental Perception, Attitudes, and Values. Nova York: Columbia University Press, 1990 [1974], cap. 14.

${ }^{14}$ FOUCAULT, Michel. Aula de 18 de janeiro de 1978. In: FOUCAULT, Michel. Seguranza, territorio, población. Curso no Collège de France (1977-1978). Buenos Aires: FCE, 2006, p. 45.

${ }^{15}$ Ocupei-me dessa "onda de assaltos" em CAIMARI, Lila. Modernidades delictivas. Buenos Aires en la era del "pistolerismo". Desenvolvimento Económico. Revista de Ciencias Sociales, n. 195, out-dez. 2009, p. 389-419.

${ }^{16}$ Polícia de la Capital. Memoria de Iinvestigaciones, 1935, p. 230.

${ }^{17}$ Caras y Caretas. 16 de março de 1929, s/p.

18 "Desbordes de incultura". El Mundo, 3 de dezembro de 1933.

19 "Candidatos a milionários". El Mundo, 21 de dezembro de 1929.

${ }^{20}$ Jogo que consiste em apostar na última ou nas últimas cifras dos prêmios maiores da loteria. Nota do Tradutor.

${ }^{21}$ ARLT, Roberto. La mujer que juega a la quiniela. In: Idem. Obras. Tomo II. Buenos Aires: Losada, 1998, p. 192.

22 BÉJAR, María Dolores. El régimen fraudulento. La política en la provincia de Buenos Aires, 1930-1943. Buenos Aires: Siglo Veintiuno, 2005, p. 161. Para uma análise das sucessivas propostas reguladoras, ver PEDETTA, Marcelo. Cara y cruz. 
Estado, juego oficial y juego clandestino antes de 1936. Comunicação apresentada em Jornadas de discusión sobre delito, polícia y justicia en perspectiva historica (siglos XIX y XX), Buenos Aires, Universidad de San Andrés, junho de 2010. O Partido Conservador é o principal ator político da Província de Buenos Aires no período aqui considerado.

23 “A repressão do jogo". La Prensa, 15 de fevereiro de 1931; reproduzido em La Libertad, 16 de fevereiro de 1931, p. 3.

${ }^{24}$ Entrevista do ex-empregado do cassino de Mar del Plata, Ricardo N. Lombardi, realizada em maio de 2008 por Marcelo Pedetta. Archivo de Historia Oral, Departamento de Historia, Facultad de Humanidades, UNMdP. Agradeço a Marcelo Pedetta o acesso a essa fonte.

${ }^{25}$ Editorial "O desenvolvimento do jogo". La Libertad, 8 de julho de 1933, p. 3. Grifo meu.

${ }^{26}$ La Prensa, 2 de março de 1933.

27 "Servicios policiales en Avellaneda”. La Nación, 14 de outubro de 1929.

${ }^{28}$ La Prensa, 2 de março de 1933. "Com a cumplicidade da polícia sujeitos apanhados pelo oficialismo violam descaradamente determinada lei. Só falta um hipódromo”, La Libertad, terça-feira, 13 de setembro de 1932, p. 1. La Prensa, 3 de abril de 1933, reproduzido em La Libertad, 4 de abril de 1933, p. 3. "Funcionam clandestinos no coração de Avellaneda. Em locais não muito distantes da chefatura de polícia, muitas mulheres exercem a prostituição", La Libertad, 9 de agosto de 1933 , p. 5.

${ }^{29}$ PIGNATELLI, Adrián. Ruggierito. Política y negocios sucios en la Avellaneda violenta de 1920 y 1930. Buenos Aires: Nueva Mayoría, 2005. p. 47.

30 Sobre a reforma de Fresco, ver BARRENECHE, Osvaldo. La reorganización de las policías en las provincias de Buenos Aires y Córdoba, 1936-1940. In: MOREYRA, B. y MALLO, Silvia. Procesos amplios, experiencia y construcción de las identidades sociales. Córdoba y Buenos Aires, siglos XVIII-XX. Córdoba: Centro de Estudios “Prof. C. Segreti”/UNC, 2007.

${ }^{31}$ El Mundo. 6 de fevereiro de 1933, p. 12.

${ }^{32}$ El Mundo, 22 de outubro de 1933, p. 12. Sobre as representações jornalísticas de Ruggiero, ver Ceechi, Ana. Polifónicas imágenes delictivas: narrar a Ruggierito. Espéculo. Revista de estudios literarios. Universidad Complutense de Madrid. Disponível em <http://www.ucm.é/info/especulo/numero45/polimag.html>

33 "Informaçóes de Avellaneda. Um empreiteiro de obras foi assassinado ontem, a tiros, por indivíduos que desapareceram em seguida”. La Nación, 25 de outubro de 1929; "Houve ontem um violento tiroteio em Valentín Alsina. Mais de 20 tiros foram trocados entre os dois bandos. O tipo conhecido por 'Gallego López' ficou gravemente ferido”. La Libertad, 11 de fevereiro de 1933, p. 5; "Explodiu outra bomba em uma padaria”. La Libertad, 24 de agosto de 1931, p. 1.

34 "Foi assassinado o major Rosasco". La Libertad, 12 de junho de 1931, p. 1; "Crivado de balas, foi assassinado o major José W. Rosasco (...). La Opinión, 12 de junho de 1931, p. 1. Designado interventor da polícia de Avellaneda após o golpe de Estado, Rosasco levou muito a sério a tarefa de "limpeza" encomendada pelo presidente José Félix Uriburu. Sua breve gestão no subúrbio industrial incluiu o fuzilamento de dois presos vinculados à rede de negócios de Ruggiero, executados na delegacia após a sentença sumária de um Conselho de Guerra, improvisado ali mesmo. De seu posto suburbano, Rosasco liderou os ataques mais duros contra o anarquismo "expropriador". No momento de sua morte, tinha acabado de prender o ativista Gino Gatti, membro do bando de Di Giovanni (já fuzilado) e Roscigna (encarcerado), e de prender mais de quarenta suspeitos em uma batida. Embora o crime nunca tenha sido completamente esclarecido, tudo indica que o espetacular golpe foi uma vingança das vítimas provenientes deste setor (e que os executores chegam a Avellaneda a partir da Capital).

35 "Como os gangsters de Chicago, os pistoleiros criollos de Morón utilizaram metralhadoras. Há muitos pontos de contato nos procedimentos usados por esses bandos". Crítica, 20 de fevereiro de 1935, p. 12; "Em Avellaneda, os mortos matam". Ahora, $1^{\circ}$ de agosto de 1935 , p. 28.

${ }^{36}$ Suprema Corte de Justiça da Província de Buenos Aires. Justicia Criminal e Delincuencia del sigo XX. La Plata: 1939. Cap. Depto. de Avellaneda.

${ }^{37}$ Para este panorama consultei o matutino La Libertad, editado em Avellaneda e que cobre a zona sul (Lanús, Villa Dominico, Sarandí, Valentín Alsina, Wilde). A visibilidade atribuída a esses incidentes depende dos contextos políticos. Tratandose de um matutino radical, exibe ruidosamente os problemas vinculados à gestáo conservadora de Barceló, que se renova em 1930. O segundo diário local consultado, La Opinión, encarna o conservadorismo bonaerense.

${ }^{38}$ La Libertad, 17 de outubro de 1929. A relação entre o endurecimento policial portenho e o aumento do delito organizado em Avellaneda é narrada no diário local La Opinión, no resumo que fez da obra policial do major Rosasco, 13 de junho de 1931 , p. 1.

${ }^{39}$ A pujante comunidade avellanedense, afirma La Libertade em editorial, vive abandonada à sua sorte: "(...) as pessoas ficam entregues ao acaso e a vida e os bens dos moradores dependem da sorte”. Sobre a situação da cidade ver o editorial "A segurança pública", em La Libertad, 16 de junho de 1931; Editorial "Campanhas contra o jogo de azar em Avellaneda". La Libertad, 8 de julho de 1931; Editorial "Avellaneda vive à mercê de sua magestade (sic) o delinquente". La Libertad, 26 de setembro de 1932; "Avellaneda encontra-se à mercê da delinquência". La Libertad, 8 de novembro de 1932, p. 5; "A cumplicidade do silêncio policial. Valentín Alsina à mercê da delinquência". La Libertad, 10 de setembro de 1932, p. 5; "É alarmante a sucessáo de assaltos e roubos em Lanús Oeste". La Libertad, 15 de fevereiro de 1933, p. 5. 
${ }^{40}$ Comunicação apresentada na mesa-redonda "Às margens da cidade: violência urbana, crime e pobreza", no âmbito do Simpósio Internacional História e Margem, promovido pelo Programa de Pós-graduação em História Social da Universidade Federal do Rio de Janeiro (UFRJ), entre 18 e 20 de outubro de 2010.

Referências bibliográficas

ARLT, Roberto. Obras. Tomo II. Buenos Aires: Losada, 1998.

ARLT, Roberto. Los siete locos. In. Novelas. Buenos Aires: Losada, 1997 [1929].

BARRENECHE, Osvaldo. La reorganización de las policías en las provincias de Buenos Aires y Córdoba, 1936-1949. In: MOREYRA, Beatriz; MALLO, Silvia (Coords.). Experiencia y construcción de las identidades sociales. Córdoba y Buenos Aires, Siglos XVIII-XX. Córdoba: Centro de Estudios Históricos "Prof. Carlos A.S. Segreti”, 2007.

BÉJAR, María Dolores. El régimen fraudulento. La política en la provincia de Buenos Aires, 1930-1943. Buenos Aires: Siglo Veintiuno, 2005.

BORGES, Jorge Luis. La muerte y la brújula. In: . Ficciones. Buenos Aires: Emecé, 1996 [1944].

CAIMARI, Lila. Modernidades delictivas. Buenos Aires en la era del "pistolerismo". Desarrollo Económico. Revista de Ciencias Sociales, n. 195, out-dez. 2009, p. 389-419.

En guerra contra el hampa. Policía y modernización tecnológica en el Buenos Aires de los años treinta. In: BOHOSLAVSKY, E., CAIMARI, L. y SCHETTINI, C. (Eds.). La policía en perspectiva histórica. Argentina y Brasil (desde el siglo XIX a la actualidad).

Disponível em <http://www.crimenysociedad.com.ar/files $>$

CARIDE, Horacio. La idea del conurbano bonaerense, 1925-1947. Documento de Trabajo No 14. San Miguel: Instituto del Conurbano, UNGS, 1999.

. Una aproximación a la historia prostibularia de Buenos Aires en tiempos de la "legalidad". Trabajo presentado en Fuera de la ley. Jornadas de discusión sobre delito, policía y justicia en perspectiva histórica (siglos XIX y XX). Buenos Aires: Universidad de San Andrés, 17 e 18 de junho de 2010.

CARIDE, Horacio e NOVICK, Alicia. La construction de la banlieue à Buenos Aires. In: RIVIERE D'ARC, H. (Dir.). Nommer les nouveaux territoires urbains. Paris: UNESCO/Editions de la Maison des Sciences de l'Homme, 2001.

CECCHI, Ana. Polifónicas imágenes delictivas: narrar a Ruggierito. Espéculo. Revista de estudiosliterarios. Universidad Complutense de Madrid. Disponível em <http://www.ucm.é/info/especulo/numero45/ polimag.html>

FOUCAULT, Michel. Seguridad, territorio, población. Curso en el Collège de France (1977-1978). Buenos Aires: Fondo de Cultura Económica, 2006.

GALEANO, Diego. La policía en la ciudad de Buenos Aires, 1867-1880. Tesis de Maestría en Investigación Histórica. Universidad de San Andrés, 2010.

GAYOL, Sandra. Sociabilidad en Buenos Aires. Buenos Aires: Ediciones del Signo, 2000.

GORELIK, Adrián. La grilla y el parque. Espacio público y cultura urbana en Buenos Aires, 18871936. Bernal: UNQ, 1998.

GUY, Donna. El sexo peligroso. La prostitución legal en Buenos Aires, 1875-1955. Buenos Aires: Sudamericana, 1994. 
KALIFA, Dominique. Crime et culture au XIXe siècle. Paris: Perrin, 2005.

LIERNUR, Jorge F. Arquitectura en la Argentina del siglo XX. La construcción de la modernidad. Buenos Aires: Fondo Nacional de las Artes, 2001.

LIERNUR, Jorge F e SILVESTRI, Graciela. El torbellino de la electrificación. Buenos Aires, 1880-1930. In: - El umbral de la metrópolis. Transformaciones técnicas y cultura en la modernización de Buenos Aires, 1870-1930. Buenos Aires: Sudamericana, 1993.

PEDETTA, Marcelo. Cara y cruz. Estado, juego oficial y juego clandestino antes de 1936. Comunicação apresentada nas Jornadas de discusión sobre delito, policía y justicia en perspectiva histórica (siglos XIX y XX). Buenos Aires, Universidad de San Andrés, junho de 2010.

PIGNATELLI, Adrián. Ruggierito. Política y negocios sucios en la Avellaneda violenta de 1920 y 1930. Buenos Aires: Nueva Mayoría, 2005.

ROMARIZ, José. La Semana Trágica. Buenos Aires: Editorial Hemisferio, 1952.

SCHIVELBUSCH, Wolfgang. Disenchanted Night: The Industrialization of Light in the Nineteenth Century. Berkeley, Califórnia: University of California Press, 1995.

TUAN, Yi-Fu . Topophilia. A Study of Environmental Perception, Attitudes, and Values. Nova York: Columbia University Press, 1990 [1974].

VAPÑARSKY, César. La Aglomeración Gran Buenos Aires. Expansión espacial y crecimiento demográfico entre 1869 y 1991. Buenos Aires: EUDEBA, 2000. 